\title{
PENGEMBANGAN BAHAN AJAR TARIKH ISLAM UNTUK SISWA KELAS VIII SMP MUHAMMADIYAH BOARDING SCHOOL YOGYAKARTA
}

\section{DEVELOPMENT OF ISLAMIC HISTORY TEACHING MATERIALS FOR CLASS VIII STUDENTS OF YOGYAKARTA MUHAMMADIYAH BOARDING SCHOOL}

\author{
Yumidiana Tya Nugraheni \\ Universitas Islam Negeri Sunan Kalijaga Yogyakarta, Indonesia \\ Email: yumidianatya@gmail.com
}

\begin{abstract}
Abstrak
Belum tersedianya bahan ajar sejarah Islam yang sesuai dengan prinsip bahan ajar dan kurikulum di Muhammadiyah Boarding School Yogyakarta menjadi latar belakang yang mendorong penulis untuk meneliti, mengembangkan dan menguji kelayakan bahan ajar sejarah Islam bagi siswa kelas VIII Muhammadiyah Boarding School Yogyakarta. Penelitian ini bertujuan untuk mengetahui, mengembangkan dan menguji kesesuaian bahan ajar sejarah Islam yang digunakan untuk siswa kelas VIII di Muhammadiyah Boarding School Yogyakarta. Penelitian ini menggunakan pendekatan kualitatif dan kuantitatif dengan jenis penelitian pengembangan. Teknik pengumpulan data dalam penelitian ini menggunakan metode observasi, wawancara, dan angket. Subjek tes dalam penelitian ini adalah guru sejarah Islam dan siswa kelas VIII Muhammadiyah Boarding School Yogyakarta. Hasil penelitian ini menghasilkan produk berupa bahan ajar sejarah Islam untuk siswa kelas VIII Muhammadiyah Boarding School Yogyakarta yang berjudul "alTarikh al-Islami (fi Sirah Rasulillah Shallah 'alaihi wa Sallam)." Setelah dilakukan uji validasi dari ahli, dari aspek tampilan, presentasi dan pembelajaran didapatkan hasil dengan kategori sangat baik. Berdasarkan hasil tanggapan guru dan siswa dari aspek, isi dan materi didapatkan hasil dengan kategori "sangat baik." Dengan demikian, dapat disimpulkan bahwa bahan ajar layak digunakan dalam pembelajaran agama Islam.
\end{abstract}

Kata Kunci: pengembangan, bahan ajar, sejarah Islam

\begin{abstract}
The unavailability of Islamic history teaching materials in accordance with the principles of teaching materials and curriculum of the Muhammadiyah Boarding School of Yogyakarta is a background that encourages writers to research, develop and test the feasibility of Islamic history teaching materials for students in class VIII of Muhammadiyah Boarding School of Yogyakarta. This reseach aims to determine, develop and test the appropriateness of Islamic history teaching materials used for students of class VIII at Muhammadiyah Boarding School of Yogyakarta. This research uses qualitative and quantitative approaches to the type of research and development. Data collection techniques in this research used the method of observation, interviews, and
\end{abstract}


questionnaires. The test subjects in this research were Islamic history's teachers and VIII grade students of Muhammadiyah Boarding School of Yogyakarta. The results of this research produced a product in the form of Islamic history teaching materials for students of class VIII of Muhammadiyah Boarding School of Yogyakarta entitled"al-Tarikh alIslami (fi Sirah Rasulillah Shallallah 'alaihi wa Sallam)." After the validation test from the expert, from the aspects of appearance, presentation and learning got results with very good categories. Based on the results of teacher and student responses from aspects, content and material got results with the category of "very good." Thus it can be concluded that teaching materials are appropriate to be used in Islamic learning.

Keywords: development, teaching material, Islamic history

\section{A. Pendahuluan}

Pendidikan berbasis boarding school menjadi lembaga pendidikan yang diminati pada beberapa tahun terakhir. Lembaga pendidikan berbasis boarding school mengalami perkembangan yang signifikan setiap tahunnya. Salah satu lembaga pendidikan boarding school yang mengalami perkembangan pesat adalah Muhammadiyah Boarding School (MBS) Prambanan Yogyakarta. ${ }^{1}$ MBS merupakan sekolah yang diminati oleh masyarakat, karena MBS memiliki kurikulum terpadu. Kurikulum terpadu yang diterapkan di MBS adalah pendidikan dengan program perpaduan antara Diknas yang mengacu pada KTSP dan kurikulum pesantren modern. Keterpaduan kurikulum yang ada diperkuat dengan inovasi pendidikan berbasis pesantren. Selain itu MBS juga memiliki program kepondokan yang berisikan qira'atul kutub, tahfidz al-Qur'an dan al-Hadits, al-lughah al-yaumiyah, olahraga, beladiri, kepanduan, dan lain sebagainya. ${ }^{2}$

Kurikulum pesantren terdiri dari berbagai mata pelajaran keagamaan, salah satunya adalah pelajaran Tarikh Islam. Pelajaran Tarikh Islam merupakan pelajaran wajib. Pelajaran tersebut memberikan pengetahuan tentang peristiwa-peristiwa masa lalu yang melingkupi permasalahan sosial, politik, ekonomi, maupun agama. ${ }^{3}$ Dalam pendidikan agama Islam, Tarikh Islam merupakan materi pengembang personal, yaitu materi yang tidak secara langsung meningkatkan keberagamaan ataupun toleransi

\footnotetext{
${ }^{1}$ PPM. Muhammadiyah Booarding School Yogyakarta, Buku Agenda PPM. Muhammadiyah Booarding School Yogyakarta, 35

${ }^{2}$ Ibid., 28

${ }^{3}$ Zuhairini, Sejarah Pendidikan Islam (Jakarta: Bumi Aksara, 1995), Cet. Ke-IV, 2
} 
Yumidiana Tya Nugraheni: Pengembangan Bahan Ajar Tarikh Islam untuk Siswa Kelas VIII SMP Muhammadiyah Boarding School Yogyakarta

beragama, tetapi mampu membentuk kepribadian yang sangat diperlukan dalam kehidupan beragama. ${ }^{4}$

Buku Tarikh Islam yang digunakan di MBS adalah buku "Khulashah Nur alYaqin." Buku tersebut berisi gambaran tentang kehidupan para pendahulu Islam tersebut disajikan dalam bentuk kisah atau cerita. Setiap cerita terdapat ide, tujuan, imajinasi, bahasa dan gaya bahasa. Unsur-unsur tersebut dapat mempengaruhi kecerdasan emosional setiap orang. Setiap orang yang membaca sebuah cerita secara mendalam maka orang itu mampu masuk dan merasakan beberapa nilai-nilai kebaikan. ${ }^{5}$ Penyajian dalam bentuk cerita memungkinkan para pembacanya untuk meneladani kehidupan figur-figur sejarah melalui perilaku mereka. ${ }^{6}$ Keteladanan merupakan bagian dari sejumlah metode paling ampuh dan efektif dalam mempersiapkan dan membentuk anak secara moral, spiritual dan sosial. ${ }^{7}$

Peneliti telah melakukan pengambilan data awal melalui wawancara dengan guru pengampu Tarikh Islam mengenai kegiatan pembelajaran Tarikh Islam. Hasil dari wawancara menunjukkan bahwa salah satu kendala dalam pembelajaran Tarikh Islam adalah berkaitan dengan bahan ajar yang digunakan. Bahan ajar yang digunakan adalah buku Khulashah Nur al-Yaqin. Menurut guru pengajar, buku ini memiliki beberapa kelemahan dalam pembelajaran, di antaranya adalah pemaparan sejarah yang terlalu singkat, tampilan yang kurang menarik, serta kurangnya inovasi dan kreativitas sehingga kesan dari buku ini adalah monoton dan tidak menarik untuk dipelajari. ${ }^{8}$

Selain wawancara terhadap pengajar Tarikh Islam, peneliti juga telah melakukan observasi awal berupa angket yang dibagikan pada siswa kelas VIII mengenai pembelajaran Tarikh Islam. Data dari hasil angket yang dibagikan menunjukkan bahwa, pelajaran Tarikh Islam merupakan salah satu pelajaran yang diminati oleh para santri. Metode yang digunakan oleh guru juga dianggap cukup oleh para siswi, namun dalam proses pembelajaran Tarikh Islam terdapat satu kendala, yaitu penggunaan buku klasik yang dianggap sulit dipelajari oleh para siswa. Kesulitan buku tersebut lebih dipengaruhi oleh tampilan buku yang tidak menarik, tidak adanya media pendukung, serta penggunaan bahasa Arab yang tidak didukung oleh ketersediaan kosa kata. $\mathrm{Ke}-2,16$

${ }^{4}$ Chabib Thoha et.al., Metodologi Pengajaran Agama (Yogyakarta: Pustaka Pelajar,2004), Cet.

${ }^{5}$ Abdul Aziz Abdul Majid, Mendidik dengan Cerita (Bandung: Remaja Rosdakarya, 2008), Cet. $\mathrm{Ke}-\mathrm{IV}, 4$

${ }^{6}$ Ebrahim Khan, Kisah Kisah Teladan (Yogyakarta: Mitra Pustaka, 2003), Cet. Ke-III, vi

${ }^{7}$ Abdullah Nashih Ulwan, Pendidikan Anak Menurut Islam Kaidah Kaidah Dasar (Bandung: Remaja Rosdakarya, 1992), 2

${ }^{8}$ Sri Qona'ah, Wawancara, Tanggal 12 Oktober 2019 pukul 09.30 
Dengan melihat hasil wawancara dari guru pengajar Tarikh Islam dan hasil dari angket yang dibagikan untuk para siswa menunjukkan bahwa bahan ajar Tarikh Islam yang digunakan dalam pembelajaran siswa kelas VIII SMP Muhammadiyah Boarding School terdapat beberapa komponen bahan ajar yang belum terpenuhi. Komponen yang belum terpenuhi tersebut dalam aspek grafika dan sistematika penyajian. Analisis bahan ajar tersebut didasarkan pada konsep bahan ajar berbasis kontekstual yang harus memperhatikan tujuan mata pelajaran yang harus memuat prinsip-prinsip umum penulisan bahan ajar antara lain: keilmuan, bahasa, keterbacaan dan grafika. ${ }^{9}$ Selain itu, bahan ajar juga merupakan salah satu komponen pokok dalam pembelajaran yakni sebagai sumber belajar selain tujuan pembelajaran, peserta didik, pengalaman belajar serta evaluasi pembelajaran. ${ }^{10}$ Dengan demikian keberadaan bahan ajar ini menjadi penting dalam proses pembelajaran.

\section{B. Metode Penelitian}

\section{Jenis Penelitian}

Penelitian ini menggunakan pendekatan kualitatif dan kuantitatif dengan jenis penelitian dan pengembangan R\&D (Research and Development). R\&D adalah metode penelitian yang secara sengaja, sistematis, bertujuan untuk mencari temukan, merumuskan, memperbaiki, mengembangkan, menghasilkan, menguji keefektifan produk, model, metode, jasa, prosedur tertentu yang lebih unggul, baru efektif, efisien, produktif dan bermakna. Dalam pelaksanaan penelitian dan pengembangan ada beberapa metode yang digunakan, yaitu: deskriptif, evaluative dan eksperimental.

\section{Subjek Penelitian}

Subjek uji coba dalam penelitian ini adalah guru Tarikh Islam kelas VIII dan siswa kelas VIII SMP Muhammadiyah Boarding School Yogyakarta.

\section{Prosedur dan tahap penelitian}

Prosedur dan tahap dalam penelitian ini merujuk pada langkah-langkah R\&D berdasarkan model Borg and Gall dalam buku Sugiyono, maka prosedur dan tahapan R\&D dalam penelitian ini adalah: identifikasi potensi dan masalah, mengumpulkan informasi, desain produk, validasi desain, perbaikan desain, uji coba produk, revisi produk, uji coba pemakaian, revisi produk dan pembuatan produk secara masal. Berikut

${ }^{9}$ Kokom Komalasari, Pembelajaran Kontekstual (Bandung: Refika Aditama, 2010), Cet. Ke-II,

${ }^{10}$ Novan Ardy Wiyani, Desain Pembelajaran Pendidikan (Yogyakarta: Ar-Ruzz Media, 2013), 
merupakan bagan dari keseluruhan prosedur dan tahapan $R \& D$ yang digunakan dalam penelitian ini.

Gambar 1. Langkah-langkah penggunaan metode R\&D

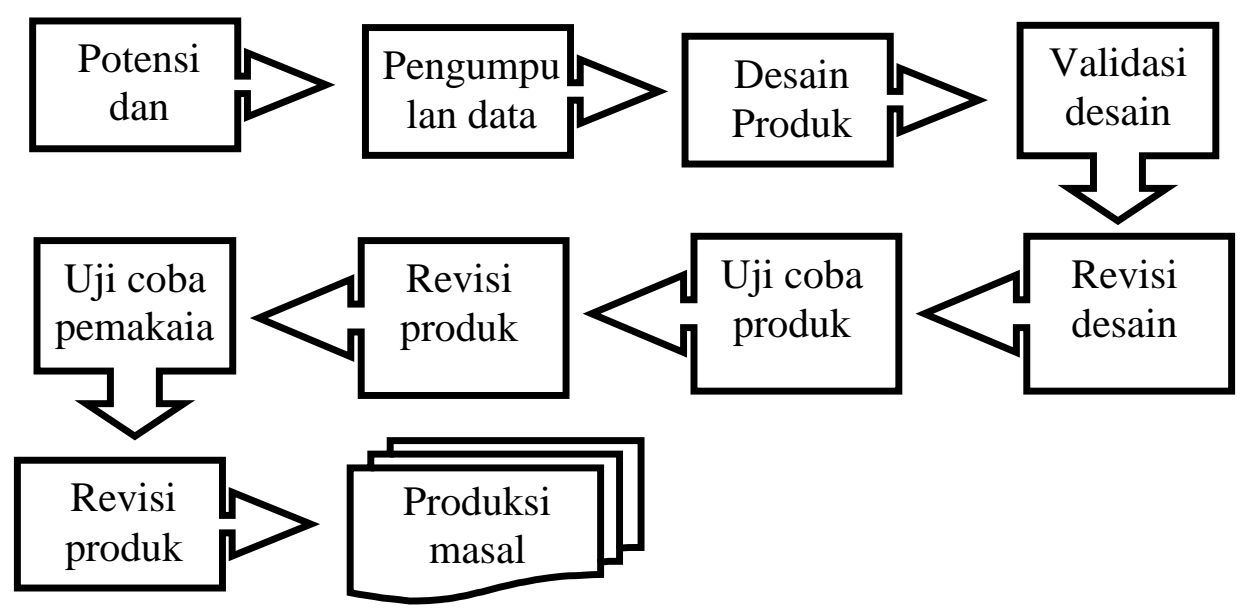

\section{Teknik Pengumpulan Data}

Teknik pengumpulan data dalam penelitian ini menggunakan beberapa metode, yaitu metode observasi, wawancara, dan angket. Observasi digunakan untuk mengamati bahan ajar yang sesuai dengan kebutuhan peserta didik, serta untuk mengamati proses pembelajaran dengan menggunakan produk yang dikembangkan. Wawancara digunakan untuk menggali data tentang bahan ajar, kebutuhan untuk pengembangan bahan ajar, juga untuk mencari tanggapan tentang revisi dan evaluasi dari hasil pengembangan bahan ajar. Angket dalam penelitian ini digunakan untuk mengumpulkan data-data kuantitatif untuk mengetahui kelayakan produk yang dikembangkan.

\section{Teknik Analisis Data}

Terdapat dua jenis data dalam analisis data dalam penelitian ini, yaitu: data kualitatif yang digunakan pada tahap awal penelitian yang berupa deskripsi analisis kebutuhan dan kesesuaian, serta analisis literature untuk pengembangan produk awal. Kedua, data kuantitatif berupa hasil ujicoba, termasuk di dalamnya adalah ujicoba validasi ahli, ujicoba awal serta ujicoba akhir. Data ini berfungsi untuk melihat kelayakan produk yang dihasilkan. Data hasil penelitian ini adalah berupa tanggapan ahli materi, ahli desain, ahli bahasa arab, guru dan siswa terhadap kelayakan produk yang telah ditinjau dari aspek materi dan aspek media.

Langkah-langkah yang digunakan untuk menentukan criteria kelayakan produk yang telah dikembangkan, sebagai berikut:

a. Data berupa skor penilaian dari ahli desain, ahli materi, ahli bahasa Arab dan yang diperoleh dari angket guru dan siswa dirubah menjadi data interval. Dalam 
angket disediakan lima pilihan untuk memberikan tanggapan terhadap kualitas produk yang dikembangkan, yaitu sangat baik (5), baik (4), cukup (3), kurang (3), dan sangat kurang (1).

b. Data skor yang diperoleh dicari rerata skor nya untuk memperbaiki penilaian terhadap produk yang telah dikembangkan, dengan menggunakan rumus:

$$
\bar{x}_{i}=\frac{\sum x}{N}
$$

Keterangan:

$\bar{x}_{i} \quad:$ Skor rata-rata

$\sum x$ : Jumlah skor

$N$ : Jumlah responden

c. Untuk memberikan penilaian kelayakan buku ajar secara keseluruhan yaitu dengan membandingkan nilai rerata total skor masing-masing komponen dengan mengkonversikan data kuantitatif ke data kualitatif dengan skala lima sesuai dengan criteria berikut:

Tabel 1. Konversi data kuantitatif ke data kualitatif skala lima

\begin{tabular}{ccc}
\hline Rumusan & Rerata Skor & Rerata Skor \\
$X>\bar{X}_{i}+1,8 \times s b_{i}$ & $>4,2$ & Sangan Baik \\
$\bar{X}_{i}+0,6 \times s b_{i}<X \leq \bar{X}_{i}+1,8 \times s b_{i}$ & $>3,4-4,2$ & Baik \\
$\bar{X}_{i}-0,6 \times s b_{i}<X \leq \bar{X}_{i}+0,6 \times s b_{i}$ & $>2,6-3,4$ & Cukup \\
$\bar{X}_{i}-1,8 \times s b_{i}<X \leq \bar{X}_{i}-0,6 \times s b_{i}$ & $>1,8-2,6$ & Kurang \\
$X \leq \bar{X}_{i}-1,8 \times s b_{i}$ & $\leq 1,8$ & Sangat kurang \\
\hline
\end{tabular}

Keterangan:

$\bar{X}_{i}($ Rerata Ideal $)=1 / 2($ Skor maksimum ideal + skor minimum ideal $)$.

$s b_{i}($ Simpang baku ideal $)=\frac{1}{6}($ Skor maksimum ideal - skor minimum ideal $)$

$\mathrm{X}=$ Skor empiris

Dalam penelitian ini, ditetapkan nilai kelayakan produk minimal berkategori "cukup," sebagai hasil penilaian baik dari validator ahli, guru maupun siswa. Jika hasil penilaian akhir (keseluruhan) pada aspek materi dan desain yang dikembangkan dengan nilai "cukup" oleh para ahli, dan jika hasil penilaian akhir (keseluruhan) dengan nilai minimal "cukup" oleh guru dan siswa, maka produk buku ajar hasil pengembangan tersebut sudah dianggap layak digunakan oleh siswa sebagai bahan pembelajaran.

\section{Landasan Teori}

\section{Pengembangan Bahan ajar}


Bahan ajar adalah segala bentuk bahan yang digunakan untuk membantu guru dalam melaksanakan kegiatan belajar mengajar, baik berupa bahan tertulis maupun bahan tidak tertulis. ${ }^{11}$ Bahan ajar adalah materi ajar yang dikemas sebagai bahan untuk disajikan dalam proses pembelajaran. ${ }^{12}$ Menurut Prastowo, bahan ajar adalah segala bahan yang disusun secara sistematis yang menampilkan sosok utuh dari kompetensi yang akan dikuasai peserta didik dan digunakan dalam proses pembelajaran dengan tujuan untuk perencanaan danpenelaahan implementasi pembelajaran. ${ }^{13}$ Beberapa prinsip bahan ajar yang harus diperhatikan, yaitu: dimulai dari yang mudah, pengulangan untuk memperkuat pemahaman, umpan balik positif, motivasi belajar yang tinggi, dan dapat mencapai tujuan. ${ }^{14}$

Dalam pengembangan bahan ajar, ada beberapa syarat penting yang harus terpenuhi dalam menyajikan materi pelajaran berupa bahan ajar yang dipergunakan siswa. Syarat-syarat tersebut adalah sebagai upaya membangun pola berfikir yang ilmiah dalam melihat segala persoalan. Dalam menyususn bahan ajar, terdaoat beberapa prinsip, yaitu: ${ }^{15}$ sesuai tahapan saintifik, kompetensi dasar dari kompetensi inti diintegrasikan pada satu unit, gambar perkataan dan kutipan menumbuhkan sikap positif, menumbuhkan minat dan rasa ingin tahu siswa, keseimbangan tugas individu dan kelompok, serta kecukupan materi untuk memahami dan melakukan kompetensi dasar.

Bahan ajar dapat dibagi ke dalam beberapa macam. Adapun macam-macam bahan ajar ini dapat diklasifikasikan berdasarkan bentuk, cara kerja dan sifatnya. ${ }^{16}$ Menurut bentuknya, bahan ajar dapat dibedakan menjadi empat macam, yaitu bahan cetak, bahan ajar dengar, bahan ajar pandang dengar dan bahan ajar interaktif. Menurut cara kerjanya, bahan ajar dibedakan menjadi lima macam, yaitu bahan ajar yang tidak diproyeksikan, bahan ajar yang diproyeksikan, bahan ajar audio, bahan ajar video, dan bahan ajar computer. Berdasarkan sifatnya, bahan ajar dapat dibagi menjadi empat macam, yaitu: pertama, bahan ajar yang berbasiskan cetak misalnya buku dan pamphlet.

\footnotetext{
${ }^{11}$ Tim Penyusun, Panduan Pengembangan Bahan Ajar (Departemen Pendidikan Nasional, 2008), 8

${ }^{12}$ Ian Konjo, "Definisi Bahan Ajar," dalam www.jaririndu.blogspot.co.id-definisi-bahan-ajar. Diakses tanggal 14 Oktober 2019.

${ }^{13}$ Andi Prastowo, Panduan Kreatif Membuat Bahan Ajar Inofatif: Menciptakan Metode Pembelajaran yang Menarik dan Menyenangkan (Yogyakarta: Diva Press, 2011), Cet. Ke-VIII, 17

${ }^{14}$ Andi Prastowo, Pengembangan Bahan Ajar Tematik (Jakarta: Kencana, 2014), 143-144

${ }^{15}$ Imas Kurniasih dan Berlin Sani, Panduan Membuat Bahan Ajar Buku Teks Pelajaran Sesuai dengan Kurikulum 2013 (Surabaya: Kata Pena, 2014), 25

${ }^{16}$ Andi Prastowo, Pengembangan Bahan Ajar Tematik..., 40-43
} 
Kedua, bahan ajar yang berbasiskan teknologi, misalnya audio cassette, slide, filmstrip, siaran radiodan film. Ketiga, bahan ajar yang digunakan untuk praktik atau proyek, misalnya kit sains, lembar observasi dan lembar wawancar. Keempat, bahan ajar yang dibutuhkan untuk keperluan interaksi manusia, misalnya telepon, handphone dan video conferencing. Bahan ajar yang digunakan dalam pembelajaran Tarikh Islam kelas VIII SMP Muhammadiyah Boarding School menurut bentuknya adalah bahan cetak yang berupa buku teks, menurut cara kerjanya adalah bahan ajar yang tidak diproyeksikan, dan menurut sifatnya adalah bahan ajar yang berbasis cetak.

Di dalam analisis kebutuhan bahan ajar ini terdapat tiga tahapan yaitu, ${ }^{17}$ menganalisis kurikulum untuk menentukan kompetensi-kompetensi yang memerlukan bahan ajar, menganalisis sumber belajar yang dilakukan berdasrkan ketersediaan, kesesuaian dan kemudahan dalam pemanfaatan dengan menginventarisasi sumber belajar yang dikaitkan dengan kebutuhan, memilih dan menentukan bahan ajar untuk memenuhi salah satu kriteria bahwa bahan ajar harus menarik dan dapat membantu peserta didik untuk mencapai kompetensi. Dalam pembelajaran Tarikh Islam kelas VIII SMP Muhammadiyah Boarding School ada beberapa standar kompetensi dan kompetensi dasar yang telah ditetapkan. Adapun bahan ajar yang digunakan dalam pembelajaran Tarikh Islam belum relevan dengan kompetensi dasar yang telah ditentukan. Bahan ajar yang digunakan juga belum maksimal dalam membantu siswa menguasai kompetensi dasar yang diajarkan.

Dalam penyusunan bahan ajar dilakukan tahapan sebagai berikut: ${ }^{18}$ Pertama, analisis kebutuhan bahan ajar yaitu kegiatan menganalisis silabus dan RPP untuk memperoleh informasi bahan ajar yang dibutuhkan peserta didik dalam mencapai kompetensi dasar yang telah ditentukan. Kedua, desain penulisan bahan ajar diawali dengan menyusun konsep bahan ajar. Ketiga, implementasi bahan ajar dalam kegiatan belajar yang dilaksanakan sesuai dengan alur yang telah digariskan dalam bahan ajar. Keempat, penilaian hasil belajar dimaksudkan untuk mengetahui tingkat penguasaan peserta didik setelah mempelajari seluruh materi yang ada dalam bahan ajar. Kelima, evaluasi dan validasi sebagai usaha perbaikan, penyesuaian dan penyempurnaan program. ${ }^{19}$ Evaluasi dimaksudkan untuk mengetahui dan mengukur apakah implementasi pembelajaran dengan bahan ajar dapat dilakukan sesuai dengan desain

\footnotetext{
${ }^{17}$ Ibid., 50

${ }^{18}$ Daryanto, Menyusun Modul: Bahan Ajar untuk Persiapan Guru dalam Mengajar (Yogyakarta: Gava Media, 2013), 16-22

${ }^{19}$ Anas Sudijono, Pengantar Evaluasi Pendidikan (Jakarta: Raja Grafindo Persada, 2008), 17
} 
Yumidiana Tya Nugraheni: Pengembangan Bahan Ajar Tarikh Islam untuk Siswa Kelas VIII SMP Muhammadiyah Boarding School Yogyakarta

pengembangannya. Bahan ajar yang digunakan dalam pembelajaran tarikh Islam kelas VIII SMP Muhammadiyah Boarding School merupakan buku klasik, sehingga desain, materi maupun evaluasi di dalamnya belum memenuhi kebutuhan yang ada.

\section{Tarikh Islam}

Secara etimologi, tarikh dalam bahasa Arab berarti buku tahunan, perhitungan tahun, buku riwayat, atau sejarah. ${ }^{20}$ Tarikh juga berarti ketentuan masa. Tarikh dalam bahasa Inggris disebut history, yang berarti pengalaman masa lampau dari pada umat manusia. Dalam bahasa Indonesia, tarikh juga dapat disebut dengan sejarah yang selanjutnya akan sering disebut dalam pembahasan. Sedangkan secara terminology, sejarah berarti keterangan yang telah terjadi di kalangan pada masa yang telah lampau atau pada masa yang masih ada. ${ }^{21}$ Adapun ilmu tarikh itu sendiri adalah suatu pengetahuan yang bermanfaat untuk mengetahui keadaan-keadaan atau kejadiankejadian yang telah lampau dalam kehidupan umat dan keadaan-keadaan atau kejadiankejadian yang masih ada di kehidupannya. ${ }^{22}$ Para ahli sejarah seringkali menyebutkan bahwa hakikat sejarah adalah penulisan kembali. Hal ini dimaksudkan bahwa sejarah itu ada karena selalu ada penulisan kembali terhadap peristiwa-peristiwa masa lampau. ${ }^{23}$

Menurut Fadil, sejarah adalah peristiwa-peristiwa masa lalu yang selalu dipandang dan dicari hubungannya dengan peristiwa-peristiwa atau kejadian-kejadian masa kini untuk selanjutnya dijadikan sebagai titik tolak atau dasar untuk memandang masa depan. Dengan demikian sejarah Islam adalah serangkaian peristiwa masa lalu yang berkaitan dengan Islam yang kemudian dijadikan tolak ukur untuk Islam masa kini. $^{24}$ Istilah sejarah Islam pada dasarnya merupakan bagian atau jenis ilmu sejarah pada umumnya, namun dalam sejarah Islam tercakup aspek-aspek keIslaman secara menyeluruh dan mencerminkan bangunan peradaban umat Islam. ${ }^{25}$ Dalam pembelajaran Tarikh Islam kelas VIII SMP Muhammadiyah Boarding School difokuskan kepada sejarah perjalanan Rasulullah, khususnya mulai dari kelahirannya sampai peristiwa hijrah ke Madinah.

Dalam pembelajaran tarikh terdapat beberapa manfaat yang dapat dipilah menjadi dua, intrinsik dan ekstrinsik. Secara intrinsik, tarikh memiliki empat manfaat,

\footnotetext{
${ }^{20}$ Supiana dan Karman, Materi Pendidikan Agama Islam (Bandung: Remaja Rosdakarya, 2012), Cet. Ke-5, 265

${ }^{21}$ Zuhairini, Sejarah Pendidikan Islam..., 1

${ }^{22}$ Moenawar Chalil, Kelengkapan Tarikh Nabi Muhammad (Jakarta: Gema Insani, 2001), 1

${ }^{23}$ Dudung Abdurrahman, Mozaik Sejarah Islam (Yogyakarta: Nusantara Press, 2011), iii 2008), 4

${ }^{24}$ Fadil, Pasang Surut Peradaban Islam dalam Lintasan Sejarah (Malang: UIN Malang Press, ${ }^{25}$ Ibid., v
} 
yaitu sejarah sebagai ilmu, sejarah sebagai mengetahui masa lampau, sejarah sebagai pernyataan sikap, dan sejarah sebagai profesi. Sedangkan secara ekstrinsik, tarikh memiliki beberapa manfaat, yaitu sebagai latar belakang, sebagai rujukan, sebagai bukti, dan sebagai pendidikan. Dalam pembelajaran Tarikh Islam, ada beberapa manfaat dan tujuan, yaitu untuk menyelidiki dan mengetahui sejauh mana kemajuan yang telah dicapai oleh umat Islam terdahulu, untuk mengetahui perkembangan peradaban Islam di berbagai negara, terutama negara-negara Islam, untuk menggali dan meninjau kembali factor-faktor yang menyebabkan kemajuan dan kemunduran Islam dalam lapangan peradaban, yang kemudian menjadi cermin bagi masa sesudahnya, untuk mengetahui dan memperbandingkan antara peradaban yang dijiwai oleh Islam dengan peradaban yang lepas dari jiwa Islam, untuk mengetahui sumbangan Islam dan umat Islam dalam lapangan peradaban umat manusia. ${ }^{26}$ Dalam pembelajaran Tarikh Islam kelas VIII SMP Muhammadiyah Boarding School memiliki beberapa tujuan, di antaranya adalah menambah pengetahuan siswa tentang sejarah Islam dengan segala peristiwa di dalamnya sehingga dapat menjadi teladan bagi siswa. Adapun tujuan utama dari pembelajaran Tarikh Islam ini adalah penanaman dan pembentukan karakter dalam diri siswa.

Dalam penulisan Tarikh Islam terdapat tiga tipe, yaitu: pertama, sejarah orisinil (original history), di mana deskripsinya sebagian besar terbatas pada karya-karya, peristiwa- peristiwa dan pemerintahan yang penulisannya menyaksikan dan menghayati sendiri atas segala apa yang ditulisnya. Kedua, sejarah pantulan (reflective history) yang deskripsinya tidak dibatasi oleh waktu yang berhubungan dengan terjadinya peristiwa itu. Ketiga, filsafat sejarah (philosophical history) adalah pengkajian dan penelaahan peristiwa sejarah dengan mempertimbangkan kebenaran atau kepalsuannya.. ${ }^{27}$

\section{Hasil Penelitian dan Pembahasan}

1. Prosedur Pengembangan Bahan Ajar Tarikh Islam untuk Siswa Kelas VIII SMP Muhammadiyah Boarding School Yogyakarta.

${ }^{26}$ Tim Penyusun, Sejarah Kebudayaan Islam (Yogyakarta: Pokja Akademik UIN Sunan Kalijaga,

${ }^{27}$ Nourouzzaman Shiddiqie, Pengantar Sejarah Muslim (Yogyakarta: Nur Cahaya, 1983), 18 
Hasil penelitian disajikan dalam bentuk grafik, tabel, atau deskriptif. Analisis dan interpretasi hasil ini diperlukan sebelum dibahas. Merujuk pada langkah-langkah R\&D berdasarkan model Borg and Gall, maka prosedur dan tahapan R\&D dalam penelitian ini adalah sebagai berikut:

\section{a. Analisis potensi dan masalah}

Tahapan ini bertujuan untuk menganalisis adanya potensi masalah yang berkaitan dengan bahan ajar Tarikh Islam siswa kelas VIII SMP Muhammadiyah Boarding School. Untuk analisis tersebut, telah dilakukan pengumpulan data awal dengan observasi, wawancara dan angket. Observasi dilakukan dalam dua tahap, yaitu observasi tentang kurikulum sekolah yang digunakan dan observasi pembelajaran Tarikh Islam di lapangan. Dari hasil observasi kurikulum yang dilakukan, diketahui bahwa bahan ajar yang digunakan dalam pembelajaran Tarikh Islam siswa kelas VIII SMP Muhammadiyah Boarding School adalah buku Khulashah Nur al-Yaqin juz 1. Alokasi pembelajaran Tarikh Islam siswa kelas VIII adalah 1 jam pelajaran dalam seminggu. Dari hasil observasi pembelajaran yang dilakukan, diketahui bahwa: pertama, pembelajaran Tarikh Islam di kelas VIII disampaikan guru dengan metode sorogan. Kedua, penyajian bahan ajar yang digunakan dalam pembelajaran Tarikh Islam kurang menarik minat siswa terhadap pelajaran Tarikh Islam. Ketiga, evaluasi yang ada dalam bahan ajar tidak menambah pengalaman belajar siswa.

Wawancara dilakukan dengan guru pengampu Tarikh Islam kelas VIII, yaitu Sri Qona'ah. Dari hasil wawancara dengan guru, diketahui bahwa salah satu kendala dalam pembelajaran Tarikh Islam adalah berkaitan dengan bahan ajar yang digunakan. Menurut guru pengajar, buku ini memiliki beberapa kelemahan dalam pembelajaran, di antaranya adalah pemaparan sejarah yang terlalu singkat, tampilan yang kurang menarik, serta kurangnya inovasi dan kreativitas sehingga kesan dari buku ini adalah monoton dan tidak menarik untuk dipelajari.

Angket digunakan untuk memperoleh informasi berupa data tentang penggunaan buku Khulashoh Nur al-Yaqin dalam pembelajaran Tarikh Islam. Jumlah responden dari angket ini adalah 50 siswa yang diambil secara acak menggunakan random sampling. Butir pertanyaan dalam angket meliputi cakupan materi, bahasa yang digunakan, latihan yang terdapat dalam buku, tampilan buku, gambar, bagan dan peta dalam buku. Penilaian dari angket tersebut menggunakan skala lima, yaitu: (1) sangat kurang, (2) kurang, (3) cukup, (4) baik, (5) sangat baik. 
Dari hasil angket yang disebarkan, kesimpulan dari rerata skor yang diperoleh adalah sebagai berikut:

\section{Tabel 2. Data Hasil Total Rerata Skor Penilaian Siswa terhadap Buku Khulashah Nur al-Yaqin}

\begin{tabular}{clcc} 
No. & \multicolumn{1}{c}{ Butir } & Rerata skor & Kategori \\
\hline 1 & Cakupan materi & 2,18 & Kurang \\
2 & Penggunaan bahasa & 2,1 & Kurang \\
3 & Latihan dalam buku & 2,24 & Kurang \\
4 & Tampilan buku & 1,66 & Sangat Kurang \\
\hline 5 & Gambar, peta dan bagan dalam buku & 1,42 & Sangat Kurang \\
\hline \multicolumn{2}{c}{ Total } & $\mathbf{1 , 9 2}$ & Kurang \\
\hline
\end{tabular}

\section{b. Pengumpulan informasi}

Dalam melakukan tahap ini, peneliti melakukan studi literatur untuk mendapatkan informasi sebanyak-banyaknya tentang teori- teori bahan ajar dan pengembangannya. Peneliti juga melakukan observasi buku ajar Tarikh Islam untuk siswa SMP yang menggunakan bahasa Arab. Observasi ini bertujuan untuk mengetahui kemungkinan tersedianya buku ajar Tarikh Islam yang sesuai. Observasi ini juga bertujuan untuk mendapatkan gambaran contoh-contoh buku ajar Tarikh Islam yang baik. Setelah ditelusuri, peneliti belum menemukan adanya buku ajar Tarikh Islam berbahasa Arab yang sesuai dengan kurikulum di Muhammadiyah Boarding School.

Dari hasil studi literature, diketahui beberapa prinsip yang perlu dilakukan dalam penyusunan bahan ajar Tarikh Islam untuk siswa kelas VIII di SMP Muhammadiyah Boarding School, yaitu: pemaparan materi yang komprehensif dan sesuai dengan kurikulum sekolah, menggunakan bahasa Arab sederhana yang sesuai kaidah yang dipelajari tingkat kelas VIII, mencantumkan kosa kata baru bagi siswa kelas VIII, mengembangkan aspek penyajian dan tampilan yang lebih menarik.

\section{c. Desain produk}

Setelah melakukan analisis terkait potensi masalah dan pengumpulan informasi terkait kebutuhan, maka data yang telah terkumpul dijadikan acuan dalam mengembangkan produk. Dalam tahap ini dilakukan penyusunan tujuan pembelajaran, menetapkan garis besar materi, mengumpulkan gambar atau ilustrasi yang diperlukan, mengembangkan materi, dan menyusun evaluasi.

Berdasarkan desain yang telah dilakukan, selanjutnya peneliti menyusun kata pengantar, membuat daftar isi, menulis uraian materi, menyajikan gambar yang dibutuhkan, menyusun evaluasi, dan menyusun daftar pustaka. Produk awal dari pengembangan siap untuk dievaluasi oleh ahli materi, ahli media, dan ahli bahasa Arab. 


\section{d. Validasi desain}

Tahap ini dimaksudkan untuk menilai keefektifan produk baru yang dihasilkan. Validasi produk dilakukan dengan menghadirkan beberapa pakar atau ahli, baik ahli materi, ahli bahasa Arab maupun ahli media yang sudah berpengalaman untuk menilai produk baru yang dihasilkan agar diketahui kelemahan dan kekurangannya.

Dalam tahap ini, peneliti meminta tanggapan dan penilaian kepada: 1) dua orang bagian kurikulum pondok pesantren Muhammadiyah Boarding school dalam aspek pembelajaran dan materi, yaitu Roiq dan Faqihuddin 2) dua orang bagian bahasa Pondok Pesantren Muhammadiyah Boarding School dalam aspek bahasa, yaitu Ahmad Hilmi dan Tika Fitria, 3) dua orang guru teknik informatika SMK Negeri Takeran dalam aspek desain dan penyajian, yaitu Achmad Sosahuddin dan Muh. Saifullah.

\section{e. Perbaikan desain}

Setelah uji validasi ahli, selanjutnya desain diperbaiki sesuai dengan saran dan masukan yang diberikan oleh para ahli.

\section{f. Uji coba produk}

Setelah desain di validasi dan direvisi, langkah selanjutnya adalah uji coba produk. Uji coba ini dilakukan dengan eksperimen pada sampel yang terbatas. Uji coba pertama ini dilakukan dengan subyek uji coba 18 siswa kelas VIII SMP Muhammadiyah Boarding School.

\section{g. Revisi produk}

Setelah uji coba pertama, langkah selanjutnya adalah merevisi kekurangan produk yang ditemukan pada desain. Revisi ini didasarkan pada masukan dan saran, serta pengamatan dari pelaksanaan pembelajaran yang dilakukan saat uji coba yang pertama.

\section{h. Uji coba pemakaian}

Selanjutnya hasil produk yang telah direvisi diujicobakan kembali dalam lingkup yang lebih luas yang kemudian dinilai, dievaluasi kekurangan dan hambatan yang terjadi untuk perbaikan yang lebih lanjut. Uji coba pemakaian ini dilakukan dengan subyek uji coba 45 siswa kelas VIII SMP Muhammadiyah Boarding School yang terbagi menjadi 2 kelas.

\section{i. Revisi produk}


Setelah diuji coba dan ditemukan kembali adanya kekurangan produk yang dihasilkan maka produk direvisi ulang dalam rangka penyempurnaan.

\section{j. Produk akhir}

Analisis dari hasil uji coba lapangan dan revisi menghasilkan produk akhir berupa bahan ajar Tarikh Islam untuk siswa kelas VIII SMP Muhammadiyah Boarding School yang berjudul

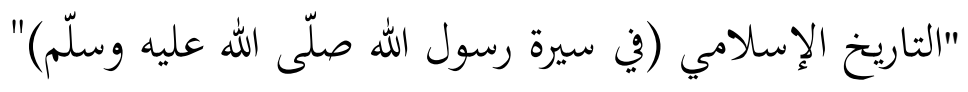

\section{Penyajian Bahan Ajar}

Bahan ajar yang telah dikembangkan terbagi dalam enam bab. Masing-masing bab terdiri dari tujuan pembelajaran umum dan khusus, peta konsep, kosa kata baru, materi inti, ringkasan dan evaluasi. Tampilan bahan ajar "at-tarikh al-Islami (fi Sirah Rasulillah Shallallah 'alaihi wa Sallam)" ini secara keseluruhan dapat dilihat pada lampiran. Berikut ini adalah uraian tampilan bahan ajar yang telah dikembangkan:

\section{a. Cover (sampul) depan}

Sampul depan disajikan dengan tampilan (layout) yang menarik dan sederhana. Tulisan judul ditampilkan dengan font dan ukuran yang jelas dan disertai dengan gambar pendukung.

\section{b. Kata pengantar}

Pada lembar pengantar ini, pengembang memberikan prakata mengenai kalimat syukur, gambaran tentang dasar penyusunan bahan ajar, serta gambaran tentang materi dan komponen bahan ajar.

\section{c. Daftar isi}

Daftar isi bertujuan untuk memberi petunjuk isi buku, sehingga dapat memudahkan pengguna untuk mencari materi pelajaran yang dikehendaki.

\section{d. Materi bab I}

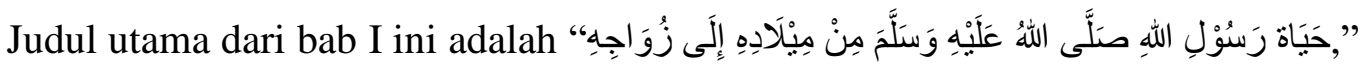
yaitu tentang kehidupan Rasulullah dari kelahiran sampai pernikahan. Peta konsep dari bab ini adalah pembahasan tentang nasab Rasulullah, orang tuanya, kelahirannya, ibu susuannya, kematian orang tuanya, pengasuhannya, perjalanan ke Syam, dan pernikahannya dengan Khadijah.

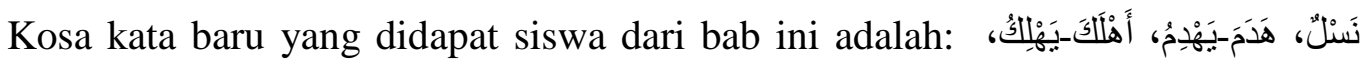

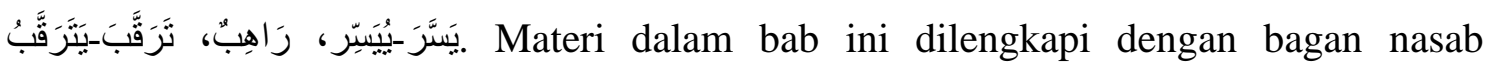


Rasulullah, peta letak Abwa' dan Syam, serta rangkuman dan soal-soal evaluasi untuk membantu siswa dalam memahami materi yang telah diajarkan.

\section{e. Materi bab II}

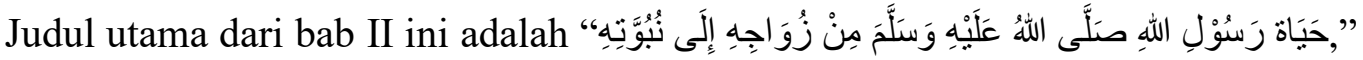
yaitu tentang kehidupan Rasulullah dari pernikahan sampai kenabian. Peta konsep dari bab ini adalah pembahasan tentang renovasi ka'bah dan peletakan Hajar Aswad, anak anak Rasulullah dengan Khadijah, perangai Rasulullah, kehidupan Rasulullah sebelum diutus menjadi rasul, serta permulaan turunnya wahyu.

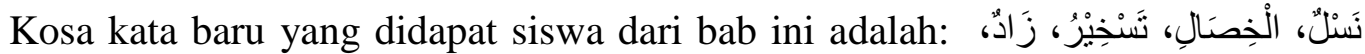
. يَقْظَةٌ Materi dalam bab ini dilengkapi dengan gambar bagian-bagian Ka'bah, gambar Hajar Aswad, gambar gua Hira' tempat turunnya wahyu, serta rangkuman dan soal-soal evaluasi untuk membantu siswa dalam memahami materi yang telah diajarkan.

\section{f. Materi bab III}

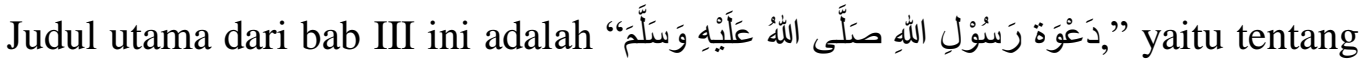
perjalanan dakwah Rasulullah. Peta konsep dari bab ini adalah pembahasan tentang keadaan Arab sebelum Islam, dakwah secara sembunyi-sembunyi, orang-orang yang pertama masuk Islam, dakwah secara terang-terangan, dan penyiksaan kaum Quraisy terhadap Rasul dan para sahabat.

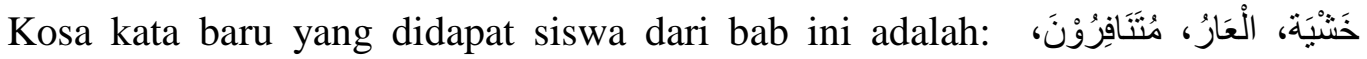

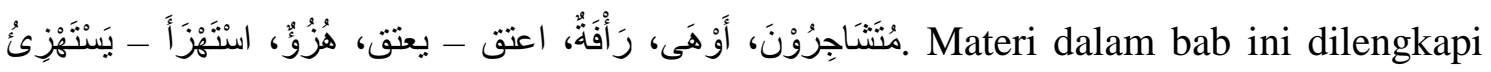
dengan gambar berhala pada zaman Jahiliyah, gambar bukit Shafa, serta rangkuman dan soal-soal evaluasi untuk membantu siswa dalam memahami materi yang telah diajarkan.

\section{g. Materi bab IV}

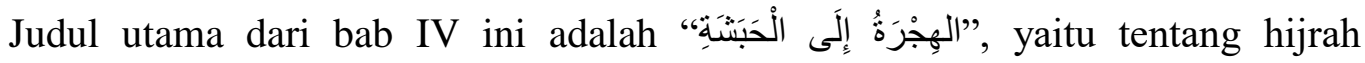
Muslimin ke Habasyah. Peta konsep dari bab ini adalah pembahasan tentang hijrah ke Habasyah yang pertama, islamnya Hamzah dan Umar, pengepungan Quraisy terhadap nabi dan keluarganya, hijrah ke Habasyah yang kedua, raja Habasyah masuk Islam, dan bebasnya Rasulullah dari pengepungan.

Kosa kata baru yang didapat siswa dari bab ini adalah: لَحقَ - يَلْحَقُ، صُلْحُع، الثنبِّعْبُ،

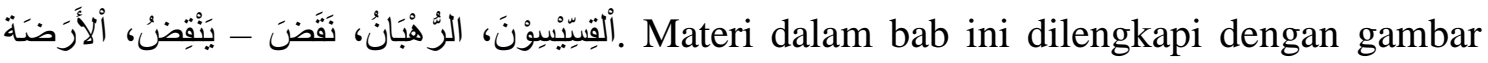
surat nabi kepada raja Habasyah, peta Habasyah, ilustrasi tentang Islamnya Raja Habasyah, serta rangkuman dan soal-soal evaluasi untuk membantu siswa dalam memahami materi yang telah diajarkan. 


\section{h. Materi bab V}

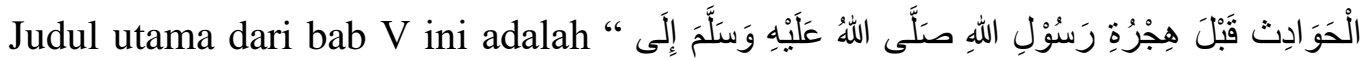
الطَّائفِ وَ هِجْرَنُهُ إلَيَهْه yang terjadi ketiha hijrah ke Thaif. Peta konsep dari bab ini adalah pembahasan tentang datangnya utusan dari Najran, kematian Khadijah dan paman Rasul, Abu Thalib, pernikahan Rasulullah dengan Aisyah dan Saudah, hijrah ke Thaif, penyiksaan kaum Thaif terhadap Nabi, dan peristiwa Isra' Mi'raj.

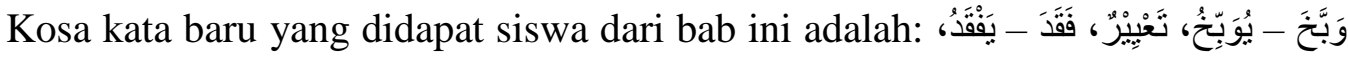
اسنتِحَانَةُّة dan soal-soal evaluasi untuk membantu siswa dalam memahami materi yang telah diajarkan.

\section{i. Materi Bab VI}

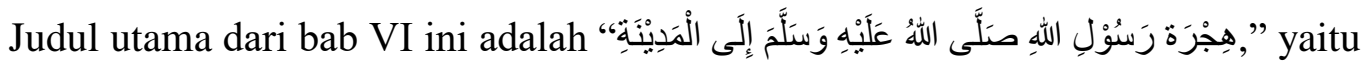
tentang peristiwa hijrah ke Madinah. Peta konsep dari bab ini adalah pembahasan tentang permulaan islamnya kaum Anshar, perjanjian'Aqabah yang pertama, perjanjian 'Aqabah yang kedua, hijrah kaum muslimin ke Madinah, perencanaan pembunuhan Nabi oleh Quraisy, Rasulullah hijrah ke Madinah dan keadaan Madinah sesampainya Rasulullah.

Kosa kata baru yang didapat siswa dari bab ini adalah: بُهْنَانٌ، افْتَرَى - يَفْنَرِي، اللِّحَاقُ صَمَّمَ - يُصَنَمِمُ، حَنَقٌُ Tsur, ilustrasi pengejaran Quraisy terhadap Nabi, gambar masjid Quba', serta rangkuman dan soal-soal evaluasi untuk membantu siswa dalam memahami materi yang telah diajarkan.

\section{j. Daftar rujukan}

Pada lembar daftar rujukan ini disajikan referensi yang digunakan sebagai acuan oleh pengembang dalam penyusunan bahan ajar.

\section{Penyajian dan Analisis Data}

Data yang telah diperoleh dari seluruh validator ahli dan juga data hasil angket siswa dan guru, disajikan dan dianalisis lebih lanjut dalam pembahasan berikut:

\section{a. Penyajian dan Analisis Data dari Ahli Desain}

Indikator dari aspek desain yaitu: pertama, aspek tampilan, meliputi desain cover, tata letak (layout), ukuran huruf, pemilihan bahasa, penggunaan kata dan istilah, keterbacaan tulisan, kejelasan cetakan dan kemudahan petunjuk. Kedua, aspek penyajian, meliputi konsistensi sistematika penyajian, keruntutan sajian, keseimbangan sajian materi antar bab, sistematika dalam bab, ragam latihan, interaktif partisipatif, 
bahan ajar disertai dengan gambar-gambar yang menarik, dan kesesuaian gambar dengan materi dalam bahan ajar. Hasil angket yang diperoleh dari validator ahli untuk aspek tampilan disajikan dalam tabel berikut:

Tabel 3. Data Hasil Penilaian Ahli Desain pada Aspek Tampilan

\begin{tabular}{|c|c|c|c|c|}
\hline \multirow{2}{*}{ No } & \multirow{2}{*}{ Aspek tampilan yang dinilai } & \multicolumn{2}{|c|}{ Skor } & \multirow{2}{*}{ Rerata total } \\
\hline & & Validator 1 & Validator 2 & \\
\hline 1 & Desai cover & 3 & 3 & 3 \\
\hline 2 & Tata letak (layout) & 4 & 4 & 4 \\
\hline 3 & Ukuran huruf & 3 & 4 & 3.5 \\
\hline 4 & Pemilihan bahasa & 4 & 5 & 4.5 \\
\hline 5 & Penggunaan kata dan istilah & 4 & 5 & 4.5 \\
\hline 6 & Keterbacaan tulisan & 3 & 4 & 3.5 \\
\hline 7 & Kejelasan cetakan & 4 & 3 & 3.5 \\
\hline 8 & Kemudahan petunjuk & 4 & 4 & 4 \\
\hline & Jumlah & 29 & 32 & 30.5 \\
\hline & Rerata & 3.6 & 4 & 3.8 \\
\hline & Kategori & Baik & Baik & Baik \\
\hline
\end{tabular}

Data hasil penilaian ahli desain pada aspek tampilan selanjutnya dianalisis secara deskriptif untuk mengetahui tingkat kelayakan buku ajar yang dikembangkan. Berdasarkan data pada tabel, diketahui bahwa penilaian ahli desain pada aspek tampilan dengan rerata masing-masing validator adalah validator satu 3,6 dan validator dua 4, sehingga diperoleh data akhir dengan rerata total untuk aspek tampilan adalah 3,8. Menurut tabel data konversi data kualitatif ke data kuantitatif skala lima, termasuk katagori baik.

Hasil angket yang diperoleh dari validator ahli untuk aspek penyajian disajikan dalam tabel berikut:

Tabel 4. Data Hasil Penilaian Ahli Desain pada Aspek Penyajian

\begin{tabular}{|c|c|c|c|c|}
\hline \multirow{2}{*}{ No } & \multirow{2}{*}{ Aspek tampilan yang dinilai } & \multicolumn{2}{|c|}{ Skor } & \multirow{2}{*}{ Rerata total } \\
\hline & & Validator 1 & Validator 2 & \\
\hline 1 & $\begin{array}{l}\text { Konsistensi } \\
\text { penyajian }\end{array}$ & 4 & 4 & 4 \\
\hline 2 & Keruntutan sajian & 3 & 4 & 3.5 \\
\hline 3 & $\begin{array}{l}\text { Keseimbangan sajian materi } \\
\text { (subtansi) antar bab }\end{array}$ & 4 & 4 & 4 \\
\hline 4 & Sistematika dalam bab & 4 & 4 & 4 \\
\hline 5 & Ragam latihan & 4 & 3 & 3.5 \\
\hline 6 & Interaktif partisipatif & 4 & 3 & 3.5 \\
\hline 7 & $\begin{array}{l}\text { Bahan ajar disertai dengan } \\
\text { gambar-gambar yang menarik }\end{array}$ & 4 & 3 & 3.5 \\
\hline 8 & $\begin{array}{l}\text { Kesesuaian gambar dengan } \\
\text { materi dalam bahan ajar }\end{array}$ & 4 & 4 & 4 \\
\hline & Jumlah & 31 & 29 & 30 \\
\hline & Rerata & 3.9 & 3.6 & 3.8 \\
\hline & Kategori & Baik & Baik & Baik \\
\hline
\end{tabular}


Data hasil penilaian ahli desain pada aspek penyajian selanjutnya dianalisis secara deskriptif untuk mengetahui tingkat kelayakan buku ajar yang dikembangkan. Berdasarkan data pada tabel di atas, diketahui bahwa penilaian ahli desain pada aspek penyajian dengan rerata masing-masing validator adalah validator satu 3,9 dan validator dua 3,6, sehingga diperoleh data akhir dengan rerata total untuk aspek tampilan adalah 3,8. Menurut tabel data konversi data kualitatif ke data kuantitatif skala lima, termasuk katagori baik.

\section{b. Penyajian dan Analisis Data dari Ahli Materi}

Indikator dari aspek materi yaitu: (1) aspek pembelajaran, meliputi kesesuaian materi dengan kompetensi dasar, kesesuaian indikator dengan kompetensi dasar, sistematika penyajian materi, gradasi penyajian materi, seleksi materi, kejelasan petunjuk belajar, kebenaran uraian materi, kejelasan sasaran program, pemberian latihan untuk pemahaman materi. (2) aspek isi/materi, meliputi materi mudah dipahami, kebenaran isi materi yang disajikan, kejelasan uraian materi, kesesuaian materi dengan siswa, kesesuaian media pembelajaran dengan materi, konsistensi penyajian, variasi bentuk soal, tingkat kesulitan soal, penggunaan bahasa dalam menjelaskan materi

Hasil angket yang diperoleh dari validator ahli untuk aspek pembelajaran disajikan dalam tabel berikut:

Tabel 5. Data Hasil Penilaian Ahli Materi pada Aspek Pembelajaran

\begin{tabular}{|c|c|c|c|c|}
\hline \multirow{2}{*}{ No } & \multirow{2}{*}{ Aspek tampilan yang dinilai } & \multicolumn{2}{|c|}{ Skor } & \multirow{2}{*}{ Rerata total } \\
\hline & & Validator 1 & Validator 2 & \\
\hline 1 & $\begin{array}{l}\text { Kesesuaian materi dengan } \\
\text { kompetensi dasar }\end{array}$ & 4 & 5 & 4.5 \\
\hline 2 & $\begin{array}{l}\text { Kesesuaian indicator dengan } \\
\text { kompetensi dasar }\end{array}$ & 4 & 5 & 4.5 \\
\hline 3 & Sistematika penyajian materi & 5 & 5 & 5 \\
\hline 4 & Gradasi penyajian materi & 5 & 5 & 5 \\
\hline 5 & Seleksi materi & 4 & 5 & 4.5 \\
\hline 6 & Kebenaran uraian materi & 4 & 5 & 4.5 \\
\hline 7 & Kejelasan sasaran program & 4 & 5 & 4.5 \\
\hline 8 & $\begin{array}{l}\text { Pemberian latihan untuk } \\
\text { pemahaman materi }\end{array}$ & 4 & 4 & 4 \\
\hline & Jumlah & 34 & 39 & 36.5 \\
\hline & Rerata & 4.3 & 4.9 & 4.6 \\
\hline & Kategori & Sangat Baik & $\begin{array}{l}\text { Sangat } \\
\text { Baik }\end{array}$ & Sangat Baik \\
\hline
\end{tabular}

Data hasil penilaian ahli materi pada aspek pembelajaran selanjutnya dianalisis secara deskriptif untuk mengetahui tingkat kelayakan buku ajar yang dikembangkan. Berdasarkan data pada tabel, diketahui bahwa penilaian ahli materi pada aspek 
pembelajaran dengan rerata masing-masing validator adalah validator satu 4,3 dan validator dua 4,9, sehingga diperoleh data akhir dengan rerata total untuk aspek pembelajaran adalah 4,6. Menurut tabel data konversi data kualitatif ke data kuantitatif skala lima, termasuk katagori sangat sangat baik.

Hasil angket yang diperoleh dari validator ahli untuk aspek isi/ materi disajikan dalam tabel berikut:

Tabel 6. Data Hasil Penilaian Ahli Materi pada Aspek Isi/Materi

\begin{tabular}{|c|c|c|c|c|}
\hline \multirow{2}{*}{ No } & \multirow{2}{*}{ Aspek tampilan yang dinilai } & \multicolumn{2}{|c|}{ Skor } & \multirow[b]{2}{*}{ Rerata total } \\
\hline & & Validator 1 & Validator 2 & \\
\hline 1 & Materi mudah dipahami & 5 & 5 & 5 \\
\hline 2 & $\begin{array}{l}\text { Kebenaran isi materi yang } \\
\text { disajikan }\end{array}$ & 5 & 5 & 5 \\
\hline 3 & Kejelasan uraian materi & 4 & 4 & 4 \\
\hline 4 & Kesesuaian materi dengan siswa & 5 & 5 & 5 \\
\hline 5 & $\begin{array}{l}\text { Kesesuaian media pembelajaran } \\
\text { dengan materi }\end{array}$ & 4 & 5 & 4.5 \\
\hline 6 & Konsistensi penyajian & 4 & 5 & 4.5 \\
\hline 7 & Variasi bentuk soal & 4 & 5 & 4.5 \\
\hline 8 & Tingkat kesulitan soal & 4 & 5 & 4.5 \\
\hline 9 & $\begin{array}{l}\text { Penggunaan bahasa dalam } \\
\text { menjelaskan materi }\end{array}$ & 5 & 5 & 5 \\
\hline & Jumlah & 40 & 44 & 42 \\
\hline & Rerata & 4.4 & 4.9 & 4.7 \\
\hline & Kategori & Sangat Baik & $\begin{array}{l}\text { Sangat } \\
\text { baik }\end{array}$ & Sangat Baik \\
\hline
\end{tabular}

Data hasil penilaian ahli materi pada aspek isi/materi selanjutnya dianalisis secara deskriptif untuk mengetahui tingkat kelayakan buku ajar yang dikembangkan. Berdasarkan data pada tabel, diketahui bahwa penilaian ahli materi pada aspek isi/ materi dengan rerata masing-masing validator adalah validator satu 4,4 dan validator dua 4,9, sehingga diperoleh data akhir dengan rerata total untuk aspek pembelajaran adalah 4,7. Menurut tabel data konversi data kualitatif ke data kuantitatif skala lima, termasuk katagori sangat baik.

\section{c. Penyajian dan Analisis Data dari Ahli Bahasa Arab}

Indikator dari aspek bahasa meliputi pemilihan bahasa, penggunaan kata dan istilah, pemilihan kosa kata, ketepatan makna dalam kosa kata, kejelasan susunan kalimat, kesesuaian penggunaan bahasa dengan kaidah bahasa Arab, kesesuaian penggunaan bahasa dengan siswa, penggunaan bahasa dalam menjelaskan materi.

Data yang diperoleh dari validasi ahli bahasa dianalisis. Hasil angket yang diperoleh dari validator ahli untuk aspek bahasa disajikan dalam tabel berikut: 
Tabel 7. Data Hasil Penilaian Ahli Bahasa Arab pada Aspek Bahasa

\begin{tabular}{|c|c|c|c|c|}
\hline \multirow{2}{*}{ No } & \multirow{2}{*}{ Aspek tampilan yang dinilai } & \multicolumn{2}{|c|}{ Skor } & \multirow{2}{*}{ Rerata total } \\
\hline & & Validator 1 & Validator 2 & \\
\hline 1 & Pemilihan bahasa & 4 & 4 & 4 \\
\hline 2 & Penggunaan kata dan istilah & 4 & 4 & 4 \\
\hline 3 & Pemilihan kosa kata & 3 & 4 & 3.5 \\
\hline 4 & $\begin{array}{l}\text { Ketepatan makna dalam kosa } \\
\text { kata }\end{array}$ & 4 & 4 & 4 \\
\hline 5 & Kejelasan susunan kalimat & 5 & 4 & 4.5 \\
\hline 6 & $\begin{array}{l}\text { Kesesuaian penggunaan bahasa } \\
\text { dengan kaidah bahasa arab }\end{array}$ & 4 & 3 & 3.5 \\
\hline 7 & $\begin{array}{l}\text { Kesesuaian penggunaan bahasa } \\
\text { dengan siswa }\end{array}$ & 4 & 5 & 4.5 \\
\hline 8 & $\begin{array}{l}\text { Penggunaan bahasa dalam } \\
\text { menjelaskan materi }\end{array}$ & 4 & 5 & 4.5 \\
\hline & Jumlah & 32 & 33 & 32.5 \\
\hline & Rerata & 4 & 4 & 4 \\
\hline & Kategori & Baik & Baik & Baik \\
\hline
\end{tabular}

Data hasil penilaian ahli bahasa pada aspek bahasa selanjutnya dianalisis secara deskriptif untuk mengetahui tingkat kelayakan buku ajar yang dikembangkan. Berdasarkan data pada tabel, diketahui bahwa penilaian ahli bahasa pada aspek bahasa dengan rerata masing-masing validator adalah validator satu 4 dan validator dua 4 , sehingga diperoleh data akhir dengan rerata total untuk aspek bahasa adalah 4. Menurut tabel data konversi data kualitatif ke data kuantitatif skala lima, termasuk katagori baik.

\section{d. Penyajian dan Analisis Data dari Guru pada Uji Coba Satu}

Setelah bahan ajar direvisi berdasarkan masukan dari validator ahli, selanjutnya dilakukan uji coba produk. Uji coba dilakukan dengan meminta tanggapan dari satu orang guru PAI di SMP Muhammadiyah Boarding School, yaitu Soraya Amrina Rosyada. Tanggapan oleh guru meliputi aspek desain dan aspek Isi/materi.

Item penilaian dari aspek desain meliputi tampilan fisik buku, kejelasan tujuan pembelajaran, penggunaan kata dan istilah dalam buku, ukuran dan jenis huruf yang digunakan dalam buku, sistematika antar bab dalam buku, gambar-gambar yang ada dalam dan kelengkapan komponen buku. Item pertanyaan dari aspek isi/materi meliputi kejelasan paparan materi pada setiap bab, kejelasan urutan penyajian materi pada tiap bab, bagan dan peta yang diberikan, kesesuaian antara gambar dan materi dalam buku, tingkat kejelasan tugas dan latihan, uraian materi dalam buku ajar, rangkuman yang diberikan, dan kosa kata dalam buku.

Dari hasil uji coba satu, diperoleh data hasil tanggapan guru dari aspek desain yang disajikan dalam tabel berikut: 


\section{Tabel 8. Data Hasil Penilaian Guru dari Aspek Desain pada Uji Coba Pertama}

\begin{tabular}{|c|c|c|c|}
\hline No & Item pertanyaan dalam aspek desain & Skor & Kategori \\
\hline 1 & Bagaimana tampilan fisik buku ajar? & 5 & Sangat baik \\
\hline 2 & Bagaimana kejelasan tujuan pembelajaran? & 4 & Baik \\
\hline 3 & $\begin{array}{l}\text { Apakah penggunaan kata dan istilah dalam } \\
\text { buku ajar mudah dimengerti? }\end{array}$ & 4 & Baik \\
\hline 4 & $\begin{array}{l}\text { Apakah ukuran dan jenis huruf yang digunakan } \\
\text { dalam buku ajar mudah dibaca? }\end{array}$ & 5 & Sangat baik \\
\hline 5 & $\begin{array}{l}\text { Bagaimana sistematika antar bab dalam buku } \\
\text { ajar? }\end{array}$ & 4 & Baik \\
\hline 6 & $\begin{array}{l}\text { Apakah gambar-gambar yang ada dalam buku } \\
\text { ajar membantu anda memahami materi? }\end{array}$ & 4 & Baik \\
\hline 7 & Bagaimana kelengkapan komponen buku ajar? & 4 & Baik \\
\hline & Jumlah & \multicolumn{2}{|c|}{30} \\
\hline & Rerata & \multicolumn{2}{|c|}{4.3} \\
\hline & Kategori & \multicolumn{2}{|c|}{ Sangat Baik } \\
\hline
\end{tabular}

Berdasarkan tabel, diketahui bahwa tanggapan guru terhadap kualitas buku ajar yang dikembangkan yaitu dengan total rerata skor 4,3. Berdasarkan tabel konversi data kuantitatif ke data kualitatif skala lima termasuk kategori sangat baik.

Dari hasil uji coba satu, diperoleh data hasil tanggapan guru dari aspek isi/materi yang disajikan dalam tabel berikut:

\section{Tabel 9. Data Hasil Penilaian Guru dari Aspek Isi/Materi pada Uji Coba Pertama}

\begin{tabular}{|c|c|c|c|}
\hline No & Item pertanyaan dalam aspek desain & Skor & Kategori \\
\hline 1 & Bagaimana kejelasan paparan materi pada setiap bab? & 4 & Baik \\
\hline 2 & $\begin{array}{l}\text { Bagaimana kejelasan urutan penyajian materi pada } \\
\text { tiap bab? }\end{array}$ & 5 & Sangat baik \\
\hline 3 & $\begin{array}{l}\text { Apakah bagan dan peta yang diberikan membantu } \\
\text { anda memahami materi? }\end{array}$ & 4 & Baik \\
\hline 4 & $\begin{array}{l}\text { Bagaiman kesesuaian antara gambar dan materi } \\
\text { dalam buku ajar? }\end{array}$ & 3 & Cukup \\
\hline 5 & Bagaimana tingkat kejelasan tugas dan latihan? & 4 & Baik \\
\hline 6 & $\begin{array}{l}\text { Apakah tugas dan latihan dalam buku ajar membantu } \\
\text { meningkatkan pemahaman anda? }\end{array}$ & 4 & Baik \\
\hline 7 & Bagaimana uraian materi dalam buku ajar? & 5 & Sangat baik \\
\hline 8 & $\begin{array}{l}\text { Apakan rangkuman yang diberikan dapat } \\
\text { mempermudah dalam pemahaman materi? }\end{array}$ & 4 & Baik \\
\hline 9 & $\begin{array}{l}\text { Apakah kosa kata dalam buku ajar membantu dalam } \\
\text { memahami materi? }\end{array}$ & 4 & Baik \\
\hline & Jumlah & & 37 \\
\hline & Rerata & & 4.1 \\
\hline & Kategori & & Baik \\
\hline
\end{tabular}


Berdasarkan tabel, diketahui bahwa tanggapan guru terhadap kualitas buku ajar yang dikembangkan yaitu dengan total rerata skor 4,1. Berdasarkan tabel konversi data kuantitatif ke data kualitatif skala lima termasuk kategori baik.

\section{e. Penyajian dan Analisis Data dari Siswa pada Uji Coba Satu}

Setelah bahan ajar direvisi berdasarkan masukan dari validator ahli, selanjutnya dilakukan uji coba produk. Uji coba dilakukan dengan menguji coba pembelajaran dengan bahan ajar dalan satu kali pertemuan dengan durasi 40 menit. Di akhir pertemuan, siswa diminta mengisi angket yang sudah disiapkan untuk mengetahui tanggapan atau respon siswa terhadap bahan ajar.

Uji coba produk pertama diikuti oleh 18 siswa kelas VIII SMP Muhammadiyah Boarding School. Item penilaian dari aspek desain meliputi tampilan fisik buku, kejelasan tujuan pembelajaran, penggunaan kata dan istilah dalam buku, ukuran dan jenis huruf yang digunakan dalam buku, sistematika antar bab dalam buku, gambargambar yang ada dalam buku dan kelengkapan komponen buku.

Dari uji coba lapangan diperoleh rerata skor hasil penilaian siswa dari aspek desain yang disajikan dalam tabel berikut:

Tabel 10. Data Hasil Total Rerata Skor Penilaian Siswa dari Aspek Desain pada Uji Coba Pertama

\begin{tabular}{clcc}
\hline No & \multicolumn{1}{c}{ Indikator } & Rerata skor & Kategori \\
\hline 1 & Tampilan fisik buku ajar & 3,9 & Baik \\
2 & Kejelasan tujuan pembelajaran & 3,9 & Baik \\
3 & Penggunaan kata dan istilah & 3,8 & Baik \\
4 & Ukuran dan jenis huruf & 4,4 & Sangat Baik \\
5 & Sistematika antar unit dan bab & 3,4 & Cukup \\
6 & Kesesuaian gambar dengan materi & 3,4 & Cukup \\
7 & Kelengkapan komponen bahan ajar & 3,8 & Baik \\
\multicolumn{3}{c}{ Jumlah } & \multicolumn{3}{c}{$\mathbf{2 6 , 6}$} \\
\multicolumn{2}{c}{ Total rerata skor } & \multicolumn{3}{c}{ Baik } \\
\hline \multicolumn{3}{c}{ Kategori } & \multicolumn{3}{c}{} \\
\hline
\end{tabular}

Item pertanyaan dari aspek isi/materi meliputi kejelasan paparan materi pada setiap bab, kejelasan urutan penyajian materi pada tiap bab, bagan dan peta yang diberikan, kesesuaian antara gambar dan materi dalam buku, tingkat kejelasan tugas dan latihan, tugas dan latihan dalam buku ajar membantu meningkatkan pemahaman, uraian materi dalam buku, rangkuman yang diberikan, kosa kata dalam buku.

Dari uji coba lapangan diperoleh rerata skor data hasil penilaian siswa dari aspek isi/ materi yang disajikan dalam tabel berikut: 


\section{Tabel 11. Data Hasil Total Rerata Skor Penilaian Siswa dari Aspek Isi/Materi pada Uji Coba Pertama}

\begin{tabular}{|c|c|c|c|}
\hline No & Indikator & Rerata skor & Kategori \\
\hline 1 & Kejelasan paparan materi pada setiap bab & 3,9 & Baik \\
\hline 2 & Kejelasan urutan penyajian materi & 3,9 & Baik \\
\hline 3 & Penggunaan bagan dan peta & 3,4 & Cukup \\
\hline 4 & Kesesuaian gambar dan materi & 3,9 & Baik \\
\hline 5 & Kejelasan tugas dan latihan & 3,7 & Cukup \\
\hline 6 & $\begin{array}{l}\text { Peran tugas dan latihan dalam peningkatan } \\
\text { pemahaman }\end{array}$ & 3,9 & Baik \\
\hline 7 & Uraian materi & 3,7 & Cukup \\
\hline 8 & Kejelasan rangkuman & 3,9 & Baik \\
\hline 9 & Penggunaan kosa kata & 3,8 & Baik \\
\hline & Jumlah & \multicolumn{2}{|c|}{34,2} \\
\hline & Total rerata skor & \multicolumn{2}{|c|}{3,8} \\
\hline & Kategori & \multicolumn{2}{|c|}{ Baik } \\
\hline
\end{tabular}

\section{f. Penyajian dan Analisis Data dari Guru pada Uji Coba Dua}

Setelah bahan ajar direvisi berdasarkan tanggapan masukan dari uji coba satu, selanjutnya dilakukan uji coba kedua. Uji coba dilakukan dengan meminta tanggapan dari dua orang guru PAI di SMP Muhammadiyah Boarding School, yaitu Sri Qona'ah. dan Heny Mufidah. Tanggapan oleh guru meliputi aspek desain dan aspek isi/materi. Item penilaian dari aspek desain meliputi tampilan fisik buku, kejelasan tujuan pembelajaran, penggunaan kata dan istilah dalam buku, ukuran dan jenis huruf yang digunakan dalam buku, sistematika antar bab dalam buku, gambar-gambar yang ada dalam dan kelengkapan komponen buku. Item pertanyaan dari aspek isi/materi meliputi kejelasan paparan materi pada setiap bab, kejelasan urutan penyajian materi pada tiap bab, bagan dan peta yang diberikan, kesesuaian antara gambar dan materi dalam buku, tingkat kejelasan tugas dan latihan, uraian materi dalam buku ajar, rangkuman yang diberikan, dan kosa kata dalam buku.

Dari hasil uji coba dua, diperoleh data hasil tanggapan guru dari aspek desain yang disajikan dalam tabel berikut:

Tabel 12. Data Hasil Penilaian Guru dari Aspek Desain pada Uji Coba Kedua

\begin{tabular}{|c|c|c|c|c|}
\hline \multirow{2}{*}{ No } & \multirow{2}{*}{ Item pertanyaan dalam aspek desain } & \multicolumn{2}{|c|}{ Skor } & \multirow{2}{*}{$\begin{array}{l}\text { Rata- } \\
\text { rata }\end{array}$} \\
\hline & & Guru 1 & Guru 2 & \\
\hline 1 & Bagaimana tampilan fisik buku ajar? & 4 & 4 & 3.5 \\
\hline 2 & Bagaimana kejelasan tujuan pembelajaran? & 5 & 5 & 5 \\
\hline 3 & $\begin{array}{l}\text { Apakah penggunaan kata dan istilah dalam } \\
\text { buku ajar mudah dimengerti? }\end{array}$ & 4 & 4 & 4 \\
\hline 4 & $\begin{array}{l}\text { Apakah ukuran dan jenis huruf yang } \\
\text { digunakan dalam buku ajar mudah dibaca? }\end{array}$ & 5 & 5 & 5 \\
\hline
\end{tabular}




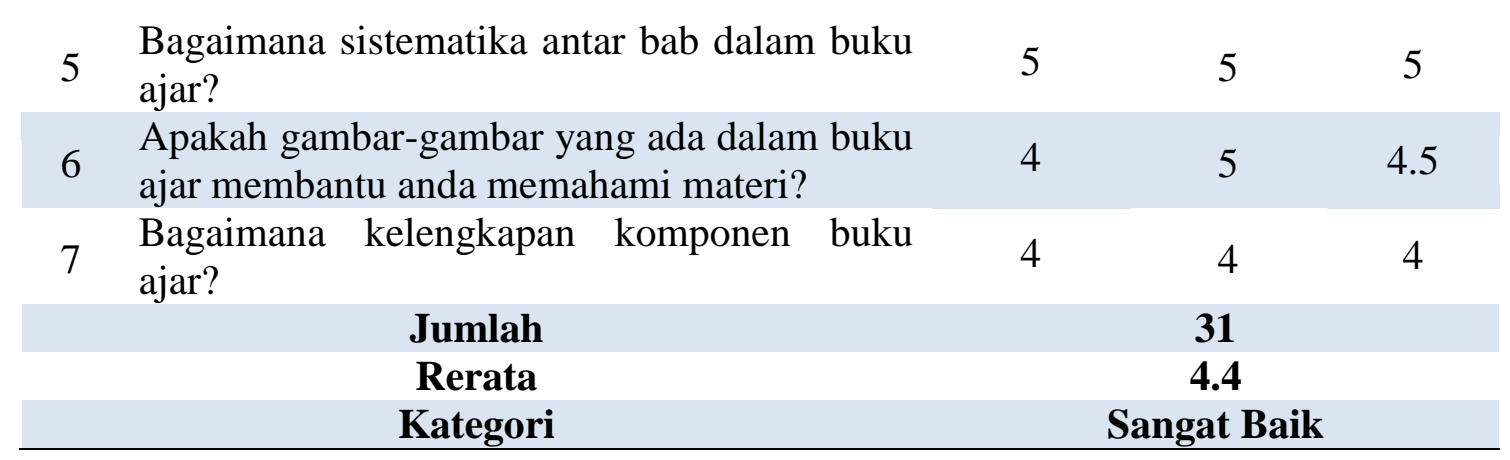

Berdasarkan tabel, diketahui bahwa tanggapan guru terhadap kualitas buku ajar yang dikembangkan yaitu dengan total rerata skor 4,4. Berdasarkan tabel konversi data kuantitatif ke data kualitatif skala lima termasuk kategori sangat baik.

Dari hasil uji coba dua, diperoleh data hasil tanggapan guru dari aspek isi/materi yang disajikan dalam tabel berikut:

\section{Tabel 13. Data Hasil Penilaian Guru dari Aspek Isi/Materi pada Uji Coba Kedua}

\begin{tabular}{|c|c|c|c|c|}
\hline \multirow{2}{*}{ No } & \multirow{2}{*}{ Item pertanyaan dalam aspek desain } & \multicolumn{2}{|c|}{ Skor } & \multirow{2}{*}{$\begin{array}{l}\text { Rata } \\
\text { rata }\end{array}$} \\
\hline & & Guru 1 & Guru 2 & \\
\hline 1 & $\begin{array}{l}\text { Bagaimana kejelasan paparan materi pada } \\
\text { setiap bab? }\end{array}$ & 4 & 4 & 4 \\
\hline 2 & $\begin{array}{l}\text { Bagaimana kejelasan urutan penyajian materi } \\
\text { pada tiap bab? }\end{array}$ & 5 & 4 & 5 \\
\hline 3 & $\begin{array}{l}\text { Apakah bagan dan peta yang diberikan } \\
\text { membantu anda memahami materi? }\end{array}$ & 4 & 5 & 4 \\
\hline 4 & $\begin{array}{l}\text { Bagaiman kesesuaian antara gambar dan } \\
\text { materi dalam buku ajar? }\end{array}$ & 4 & 5 & 4 \\
\hline 5 & $\begin{array}{l}\text { Bagaimana tingkat kejelasan tugas dan } \\
\text { latihan? }\end{array}$ & 4 & 5 & 4 \\
\hline 6 & $\begin{array}{l}\text { Apakah tugas dan latihan dalam buku ajar } \\
\text { membantu meningkatkan pemahaman anda? }\end{array}$ & 4 & 5 & 4 \\
\hline 7 & Bagaimana uraian materi dalam buku ajar? & 4 & 4 & 4 \\
\hline 8 & $\begin{array}{l}\text { Apakan rangkuman yang diberikan dapat } \\
\text { mempermudah dalam pemahaman materi? }\end{array}$ & 5 & 5 & 5 \\
\hline 9 & $\begin{array}{l}\text { Apakah kosa kata dalam buku ajar membantu } \\
\text { dalam memahami materi? }\end{array}$ & 5 & 5 & 5 \\
\hline & Jumlah & & 39 & \\
\hline & Rerata & & 4.3 & \\
\hline & Kategori & & angat baik & \\
\hline
\end{tabular}

Berdasarkan tabel, diketahui bahwa tanggapan guru terhadap kualitas buku ajar yang dikembangkan yaitu dengan total rerata skor 4,3. Berdasarkan tabel konversi data kuantitatif ke data kualitatif skala lima termasuk kategori sangat baik. 


\section{g. Penyajian dan Analisis Data dari Siswa pada Uji Coba Dua}

Setelah bahan ajar direvisi berdasarkan tanggapan dan masukan dari uji coba pertama, selanjutnya dilakukan uji coba kedua. Uji coba dilakukan dengan menguji coba pembelajaran dengan bahan ajar dalan satu kali pertemuan dengan durasi 40 menit. Di akhir pertemuan, siswa diminta mengisi angket yang sudah disiapkan untuk mengetahui tanggapan atau respon siswa terhadap bahan ajar.

Uji coba produk pertama diikuti oleh 45 siswa kelas VIII SMP Muhammadiyah Boarding School yang terbagi menjadi dua kelas. Item penilaian dari aspek desain meliputi tampilan fisik buku, kejelasan tujuan pembelajaran, penggunaan kata dan istilah dalam buku, ukuran dan jenis huruf yang digunakan dalam buku, sistematika antar bab dalam buku, gambar-gambar yang ada dalam buku dan kelengkapan komponen buku.

Dari uji coba lapangan diperoleh data rerata skordari hasil penilaian siswa dari aspek desain yang disajikan dalam tabel berikut:

Tabel 14. Data Hasil Total Rerata Skor Penilaian Siswa dari Aspek Desain pada Uji Coba Kedua

\begin{tabular}{|c|c|c|c|}
\hline No & Indikator & Rerata skor & Kategori \\
\hline 1 & Tampilan fisik buku ajar & 4,2 & Baik \\
\hline 2 & Kejelasan tujuan pembelajaran & 4,3 & Sangat Baik \\
\hline 3 & Penggunaan kata dan istilah & 4,3 & Sangat Baik \\
\hline 4 & Ukuran dan jenis huruf & 4,7 & Sangat Baik \\
\hline 5 & Sistematika antar bab & 4,2 & Baik \\
\hline 6 & Kesesuaian gambar dengan materi & 4,6 & Sangat Baik \\
\hline 7 & Kelengkapan komponen bahan ajar & 4,3 & Sangat Baik \\
\hline & Jumlah & \multicolumn{2}{|c|}{30,6} \\
\hline & Total rerata skor & \multicolumn{2}{|c|}{4,4} \\
\hline & Kategori & \multicolumn{2}{|c|}{ Sangat Baik } \\
\hline
\end{tabular}

Item pertanyaan dari aspek isi/materi meliputi kejelasan paparan materi pada setiap bab, kejelasan urutan penyajian materi pada tiap bab, bagan dan peta yang diberikan, kesesuaian antara gambar dan materi dalam buku, tingkat kejelasan tugas dan latihan, tugas dan latihan dalam buku ajar membantu meningkatkan pemahaman, uraian materi dalam buku, rangkuman yang diberikan, kosa kata dalam buku.

Dari uji coba lapangan diperoleh rerata skor data hasil penilaian siswa dari aspek isi/ materi yang disajikan dalam tabel berikut: 


\section{Tabel 15. Data Hasil Total Rerata Skor Penilaian Siswa dari Aspek Isi/Materi pada Uji Coba Kedua}

\begin{tabular}{|llcr}
\hline No & \multicolumn{1}{c}{ Indikator } & Rerata skor & Kategori \\
\hline 1 & Kejelasan paparan materi pada setiap bab & 4,2 & Baik \\
2 & Kejelasan urutan penyajian materi & 4,3 & Sangat Baik \\
3 & Penggunaan bagan dan peta & 4,3 & Sangat Baik \\
4 & Kesesuaian gambar dan materi & 4,4 & Sangat Baik \\
5 & Kejelasan tugas dan latihan & 4,2 & Baik \\
\hline 6 & Peran tugas dan latihan dalam peningkatan & 4,4 & Sangat Baik \\
& pemahaman & 4,1 & Baik \\
7 & Uraian materi & 4,5 & Sangat Baik \\
8 & Kejelasan rangkuman & 4,3 & Sangat Baik \\
9 & Penggunaan kosa kata $\quad$ Jumlah & \multicolumn{2}{c}{$\mathbf{3 8 , 7}$} \\
\multicolumn{2}{|c}{ Total rerata skor } & \multicolumn{2}{c}{ Sangat Baik } \\
\hline
\end{tabular}

\section{Revisi Produk Bahan Ajar}

Setelah dilakukan validasi dari ahli desain, ahli materi dan ahli bahasa arab, dan setelah dilakukan uji coba lapangan, terdapat revisi dari ahli dan uji coba tersebut. Setelah mendapatkan masukan, maka bahan ajar diperbaiki sesuai dengan masukan tersebut.

\section{a. Revisi Produk dari Ahli Desain}

Dari penilaian produk awal oleh ahli desain, diketahui bahwa bahan ajar Tarikh Islam 'al-Tarikh al-Islamy ( $\mathrm{fi}$ Sirah Rasulillah Shallallah 'alaih wa Sallam) secara keseluruhan sudah baik dan layak digunakan. Untuk meningkatkan kualitas produk, ahli desain memberikan saran-saran perbaikan. Saran-saran tersebut adalah cover perlu ditambahkan ornamen, warna kuning untuk cover terlalu tajam, font untuk cover kurang jelas, penggunaan background pada tulisan terlalu dominan dan perlu disederhanakan.

Dari saran-saran yang disampaikan ahli desain, sudah dilakukan beberapa revisi, yaitu menambahkan ornament dalam cover, mengganti font dalam cover, dan menyederhanakan background pada tulisan tujuan pembelajaran dan kosa kata.

\section{b. Revisi Produk dari Ahli Materi}

Dari penilaian produk awal oleh ahli materi, diketahui bahwa bahan ajar Tarikh Islam 'al-Tarikh al-Islamy (fi Sirah Rasulillah Shallallah 'alaih wa Sallam) secara keseluruhan sudah baik dan layak digunakan. Untuk meningkatkan kualitas produk, ahli materi memberikan saran-saran perbaikan. Saran-saran tersebut adalah perlu 
diperbanyak variasi soal, judul utama pada bab V perlu direvisi, beberapa materi teks terlalu panjang, perlu ditambah latihan (evaluasi) di akhir semester.

Dari saran-saran yang disampaikan ahli materi, sudah dilakukan beberapa revisi, yaitu memperbanyak variasi soal, mengganti judul pada bab V dari الِْجْرَةُ إِلَى الطَّائَفِ

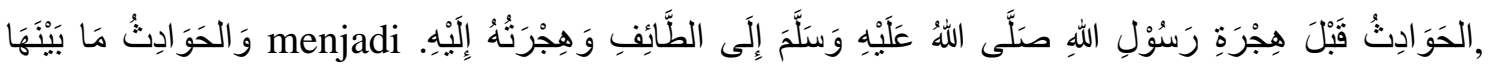
menyederhanakan beberapa teks dalam materi, dan menambahkan evaluasi di akhir semester.

\section{c. Revisi Produk dari Ahli Bahasa Arab}

Dari penilaian produk awal oleh ahli bahasa arab, diketahui bahwa bahan ajar Tarikh Islam 'al-Tarikh al-Islamy (fi Sirah Rasulillah Shallallah 'alaih wa Sallam) secara keseluruhan sudah baik dan layak digunakan. Untuk meningkatkan kualitas produk, ahli bahasa arab memberikan saran-saran perbaikan. Saran-saran tersebut adalah beberapa arti dari kosa kata perlu diperbaiki dan harakat dalam beberapa kalimat perlu dikoreksi.

Dari saran-saran yang disampaikan ahli bahasa arab, sudah dilakukan beberapa revisi, yaitu mengganti beberapa arti dalam kosa kata dan mengoreksi beberapa harakat dalam kalimat.

\section{d. Revisi Produk dari Guru dan Siswa}

Dari penilaian uji coba satu, diketahui bahwa bahan ajar Tarikh Islam 'al-Tarikh al-Islamy ( $f i$ Sirah Rasulillah Shallallah 'alaih wa Sallam) secara keseluruhan sudah baik dan layak digunakan. Untuk meningkatkan kualitas produk, guru dan siswa memberikan saran-saran perbaikan. Saran-saran tersebut adalah gambar perlu ditambahkan, beberapa peta kurang jelas.

Dari saran-saran yang disampaikan guru dan siswa pada uji coba satu, sudah dilakukan beberapa revisi, yaitu menambahkan beberapa gambar dalam materi dan mengganti beberapa peta yang kurang jelas.

\section{E. Simpulan dan Saran}

\section{Simpulan}

Bahan ajar Tarikh Islam yang digunakan untuk siswa kelas VIII SMP Muhammadiyah Boarding School berupa buku teks yang berjudul "Khulashah Nur alYaqin (fi Sirah Rasulillah Shallallah 'alaih wa Sallam) li Talamidz al-Madrasah alIbtidaiyah bi Indunisiya." Bahan ajar Tarikh Islam untuk siswa kelas VIII SMP Muhammadiyah Boarding School yang telah dikembangkan berjudul "al-Tarikh al- 
Islami (fi Sirah Rasulillah Shallallah 'alaihi wa Sallam)." Adapun struktur dari buku tersebut adalah: 1) sampul depan, 2) kata pengantar, 3) daftar isi, 4) materi bab I, 5) materi bab II, 6) materi bab III, 7) materi bab IV, 8) materi bab V, 9) materi bab VI, 10) daftar rujukan.

Setelah dilakukan uji validasi dari ahli desain, diketahui rerata total untuk aspek tampilan adalah 3,8 dengan kategori "baik." Rerata total untuk aspek penyajian adalah 3,8 dengan kategori "baik." Dengan demikian dapat disimpulkan bahwa bahan ajar layak digunakan dilihat dari aspek desain. Setelah dilakukan uji validasi dari ahli materi, diketahui rerata total untuk aspek pembelajaran adalah 4,6 dengan kategori "sangat baik." Rerata total untuk aspek isi/materi adalah 4,7 dengan kategori "sangat baik." Dengan demikian, dapat disimpulkan bahwa bahan ajar layak digunakan dilihat dari aspek isi/materi. Setelah dilakukan uji validasi dari bahasa Arab, diketahui rerata total untuk aspek bahasa adalah 4 dengan kategori "baik." Dengan demikian, dapat disimpulkan bahwa bahan ajar layak digunakan dilihat dari aspek bahasa. Berdasarkan hasil respon guru dan siswa pada uji coba kedua, diketahui bahwa dari aspek desain guru memberikan penilaian dengan rerata total 4,4 dengan kategori "sangat baik," dan murid memberikan penilaian dengan rerata total 4,4 dengan kategori "sangat baik." Dari aspek isi/materi guru memberikan penilaian dengan rerata total 4,3 dengan kategori "sangat baik," dan murid memberikan penilaian dengan rerata total 4,3 dengan kategori "sangat baik." Dengan demikian, dapat disimpulkan bahwa bahan ajar layak digunakan dalam pembelajaran Tarikh Islam.

\section{Saran}

Berdasarkan hasil pengembangan yang telah dilakukan, maka peneliti memberikan saran-saran untuk perbaikan dan pengembangan untuk penelitian selanjutnya dan juga untuk pihak terkait, di antaranya: pertama, bagi guru Tarikh Islam kelas VIII SMP Muhammadiyah Boarding School diharapkan untuk menggunakan produk pengembangan bahan ajar Tarikh Islam untuk siswa kelas VIII SMP Muhammadiyah Boarding School yang telah dikembangkan, yaitu buku "al-Tarikh alIslami (fi Sirah Rasulillah Shallallah 'alaihi wa Sallam)" sebagai bahan ajar dalam pembelajaran Tarikh Islam. Guru juga dapat memadukan bahan ajar dengan media pembelajaran lainnya. Kedua, bagi siswa diharapkan meningkatkan intensitas membaca buku-buku Tarikh Islam. Buku yang dibaca hendaknya tidak hanya terbatas pada buku ajar utama dalam pembelajaran Tarikh Islam, melainkan juga membaca dari referensi lainnya. Ketiga, bagi peneliti selanjutnya, ruang lingkup penelitian ini masih sangat 
terbatas pada pengembangan bahan ajar Tarikh Islam kelas VIII SMP Muhammadiyah Boarding School, maka dapat dilanjutkan dengan mengembangkan bahan ajar Tarikh Islam di jenjang selanjutnya. Keempat, bagi masyarakat umum diharapkan penelitian ini dapat memberikan kontribusi dan manfaat bagi pembelajaran Tarikh Islam di lembaga pendidikan lainnya.

\section{F. Daftar Pustaka}

Abdurrahman, Dudung. Mozaik Sejarah Islam. Yogyakarta: Nusantara Press, 2011.

Chalil, Moenawar. Kelengkapan Tarikh Nabi Muhammad. Jakarta: Gema Insani, 2001.

Daryanto. Menyusun Modul: Bahan Ajar untuk Persiapan Guru dalam Mengajar. Yogyakarta: Gava Media, 2013.

Fadil. Pasang Surut Peradaban Islam dalam Lintasan Sejarah. Malang: UIN Malang Press, 2008.

Khan, Ebrahim. Kisah Kisah Teladan. Yogyakarta: Mitra Pustaka, 2003, Cet. Ke-III..

Komalasari, Kokom. Pembelajaran Kontekstual. Bandung: Refika Aditama, 2010, Cet.Ke-II.

Konjo, Ian. "Definisi Bahan Ajar.” Dalam www.jaririndu.blogspot.co.id-definisi-bahanajar. Diakses tanggal 14 Oktober 2019.

Kuntowijoyo. Pengantar Ilmu Sejarah. Yogyakarta: Tiara Wacana, 2013.

Kurniasih, Imas dan Berlin Sani. Panduan Membuat Bahan Ajar Buku Teks Pelajaran Sesuai dengan Kurikulum 2013. Surabaya: Kata Pena, 2014.

Majid, Abdul Aziz Abdul. Mendidik dengan Cerita. Bandung: Remaja Rosdakarya, 2008, Cet. Ke-4.

Penyusun, Tim. Panduan Pengembangan Bahan Ajar. Departemen Pendidikan Nasional, 2008.

Sejarah Kebudayaan Islam. Yogyakarta: Pokja Akademik UIN Sunan Kalijaga, 2005.

Prastowo, Andi. Panduan Kreatif Membuat Bahan Ajar Inofatif: Menciptakan Metode Pembelajaran yang Menarik dan Menyenangkan. Yogyakarta: Diva Press, 2011, Cet. Ke-VIII.

Pengembangan Bahan Ajar Tematik. Jakarta: Kencana, 2014.

Putra, Nusa. Research \& Development Penelitian dan Pengembangan: Suatu Pengantar. Jakarta: Raja Grafindo Persada, 2011, Cet. Ke-IV.

Shiddiqie, Nourouzzaman. Pengantar Sejarah Muslim. Yogyakarta: Nur Cahaya, 1983.

Sudijono, Anas. Pengantar Evaluasi Pendidikan. Jakarta: Raja Grafindo Persada. 2008.

Sugiyono. Metode Penelitian Pendidikan. Bandung: Alfabeta, 2008.

Supiana dan Karman. Materi Pendidikan Agama Islam. Bandung: Remaja Rosdakarya, 2012, Cet. Ke-5. 
Thoha, Chabib, et.al. Metodologi Pengajaran Agama. Yogyakarta: Pustaka Pelajar, 2004, Cet. Ke-2..

Ulwan, Abdullah Nashih. Pendidikan Anak Menurut Islam Kaidah-kaidah Dasar. Bandung: Remaja Rosdakarya, 1992.

Wiyani, Novan Ardy. Desain Pembelajaran Pendidikan. Yogyakarta: Ar-Ruzz Media, 2013

Zuhairini. Sejarah Pendidikan Islam. Jakarta: Bumi Aksara, 1995, Cet. Ke-IV. 